\title{
PERANCANGAN APLIKASI MONITORING KEGIATAN PRAKTEK KERJA INDUSTRI (PRAKERIN) SISWA SMK
}

\author{
Muhammad Saidi Rahman ${ }^{1)}$, Lilis Anggraini ${ }^{2)}$, Dwi Agung Wibowo ${ }^{3)}$, Yusup Indra Wijaya ${ }^{4)}$ \\ 1) Fakultas Teknologi Informasi, Universitas Islam Kalimantan Muhammad Arsyad Al Banjari Banjarmasin \\ m.saidi.rahman@gmail.com \\ ${ }^{2)}$ Fakultas Teknologi Informasi, Universitas Islam Kalimantan Muhammad Arsyad Al Banjari Banjarmasin \\ lilis.anggraini0205@gmail.com \\ ${ }^{3)}$ Fakultas Teknologi Informasi, Universitas Islam Kalimantan Muhammad Arsyad Al Banjari Banjarmasin \\ agungfti@gmail.com \\ 4) Fakultas Teknologi Informasi, Universitas Islam Kalimantan Muhammad Arsyad Al Banjari Banjarmasin \\ yusupindra1313@gmail.com
}

\begin{abstract}
Abstrak
SMK Negeri 4 Banjarmasin merupakan salah satu sekolah SMK Negeri yang ada di Banjarmasin. SMK Negeri 4 Banjarmasin memeliki 7 program keahlian, yaitu: Rekayasa Perangkat Lunak, Tata Busana, Tata Boga, Tata Kecantikan, Akomodasi Perhotelan, Usaha Perjalanan Wisata, dan Seni Musik Populer. Banyaknya siswa yang melaksanakan kegiatan prakerin tiap tahunnya mengalami beberapa kendala seperti tidak cepatnya informasi yang didapat guru pendamping prakerin terhadap kegiatan siswa di tempat prakerin karena hanya dilakukan 1 bulan sekali. Selain itu, sulitnya membuatkan laporan-laporan yang diperlukan untuk rekapitulasi data prakerin karena data yang di proses masih menggunakan Microsoft Excel yang tentunya membuat banyak memakan waktu. Dengan adanya aplikasi monitoring kegiatan prakerin siswa berbasis web ini, guru pembimbing dapat melihat kegiatan prakerin siswa secara realtime selama melaksanakan kegiatan prakerin. Memberikan kemudahan kepada operator / admin prakerin dalam membuat laporan-laporan prakerin.
\end{abstract}

Kata kunci : monitoring, prakerin, SMK Negeri 4 Banjarmasin

\section{PENDAHULUAN}

SMK Negeri 4 Banjarmasin merupakan salah satu sekolah SMK Negeri yang ada di Banjarmasin. Sekolah ini memiliki 7 program keahlian, yaitu: Rekayasa Perangkat Lunak (RPL), Tata Busana, Tata Boga, Tata Kecantikan, Akomodasi Perhotelan, Usaha Perjalanan Wisata, dan Seni Musik Populer.

Praktek Kerja Industri (Prakerin) adalah suatu kegiatan pendidikan pelatihan dan pembelajaran yang dilakukan di dunia usaha atau dunia industri dalam upaya pendekatan atau untuk meningkatkan mutu para siswasiswi Sekolah Menengah Kejuruan (SMK). Prakerin yang dilaksanakan siswa-siswi SMK Negeri 4 Banjarmasin dalam waktu minimal 3 bulan. Selama dalam masa pelaksanaan prakerin tersebut, siswa-siswa wajib Jurnal Ilmiah "Technologia" melaporkan kegiatan harian yang telah dilakukan di tempat pelaksaan prakerin dalam buku jurnal kegiatan prakerin.

Masalah yang selama ini terjadi selama pelaksanaan PRAKERIN adalah kurang cepatnya informasi kegiatan siswa melaksanakan PRAKERIN karena harus menunggu guru pendamping melakukan monitoring ke tempat pelaksanaan PRAKERIN siswa. Selain itu, untuk membuat laporan data-data terkait PRAKERIN, seperti data tempat PRAKERIN, data siswa yang melaksanakan PRAKERIN berdasarkan tahun ajaran dan data laporan lainnya memerlukan waktu yang lama, karena penyimpanan data masih dilakukan manual melalui data file Excel. 
Beberapa penelitian yang berkaitan dengan monitoring prakerin siswa ini di antaranya: Menurut Mochamad Baiduri dan Erna Susilatawati [1] dengan adanya aplikasi ini dapat membantu siswa dan hubin dalam pendaftaran dan monitoring prakerin. Sedangkat menurut Fitri Ayu dan Nia Permatasari ${ }_{[2]}$ dengan membangun sistem ini, maka dapat memperbaiki pengelolaan kegiatan PKL, dapat mengurangi resiko terjadinya kekeliruan / kesalahan dalam pengelolaan PKL dan dapat menyajikan informasi secara cepat, tepat dan akurat. Dan menurut Septya Maharani $\mathrm{dkk}_{[3]}$ sistem yang dibangun untuk membantu, mengelola sebagai informasi bagi pihak fakultas mengetahui proses PKL yang diadakan serta sebagai media informasi bagi para user yang kemungkinan ingin melaksanakan PKL di FKTI.

Untuk mengatasi permasalahan yang telah diuraikan diatas, maka peneliti akan melakukan penelitian dengan menerapkan teknologi yang akan membantu pihak sekolah yang berjudul "Perancangan Aplikasi Monitoring Kegiatan Praktek Kerja Industri (Prakerin) Siswa Smk".

\section{METODE PENILITIAN}

Metode penelitian yang dilakukan untuk analisis, merancang dan mengimplementasikan sistem adalah dengan menggunakan metode waterfall, melalui tahapan penelitian seperti gambar berikut:

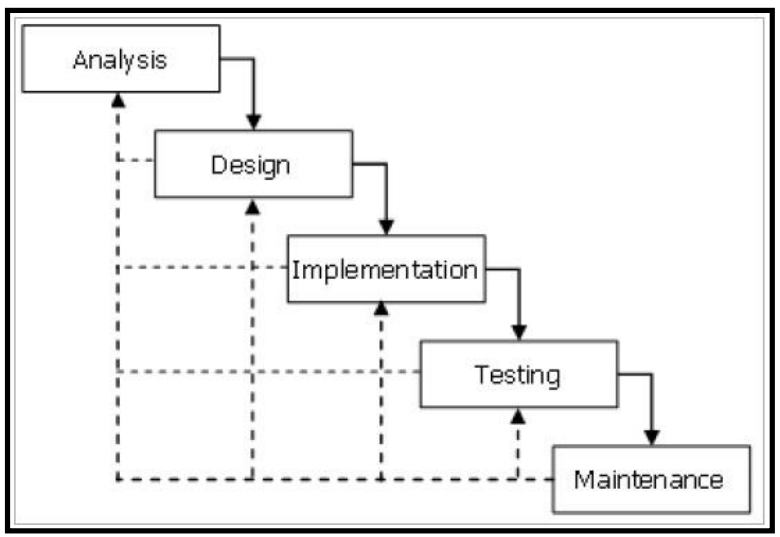

Gambar 1. Metode Waterfall
Penguraian dari suatu sistem informasi yang utuh ke dalam bagian-bagian komponennya dengan maksud untuk mengidentifikasikan dan mengevaluasi permasalahan, kesempatan, hambatan yang terjadi dan kebutuhan yang diharapkan sehingga dapat diusulkan perbaikan.

Analisis sistem ini dilakukan pada saat sebelum dibuatnya perancangan sistem, biasa dikenal dengan analisis sistem berjalan, sehingga diketahui permasalan serta apa yang dibutuhkan sehingga dibuat analisis sistem usulan

\section{b) Desain Sistem}

Pada gambar 2. Merupakan alur proses sistem di mana pengguna yang terlibat dalam sistem ini terdapat 4 pengguna yaitu siswa, guru, pembimbing prakerin dan admin prakerin sekolah.

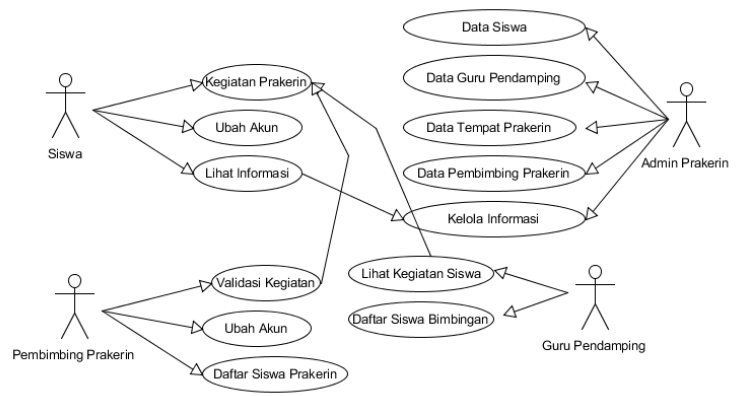

Gambar 2. Use Case Diagram

\section{HASIL DAN PEMBAHASAN}

Hasil dari perancangan aplikasi monitoring kegiatan praktek kerja industri (prakerin) siswa.

a) Antarmuka Login

Halaman login digunakan untuk melakukan verifikasi pengguna aplikasi. Untuk akun siswa, masukan nis sebagai username dan tanggal lahir sebagai password. Untuk akun guru maka gunakan nip sebagai username dan tanggal lahir sebagai password. Gambar 3 berikut adalah tampilan halaman login aplikasi. a) Analisa Sistem

Jurnal Ilmiah "Technologia" 


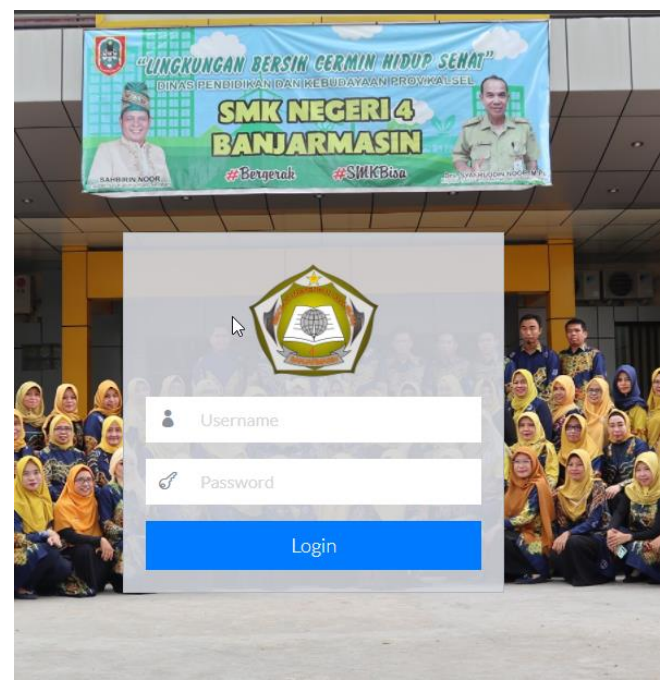

Gambar 3. Antarmuka Login

b) Antarmuka Data Kelas

Halaman data kelas menampilkan data kelas yang ada di SMK Negeri 4 Banjarmasin. Data yang ditampilkan yaitu: nama kelas, dan jumlah siswa dalam setiap kelasnya. Berikut tampilan antarmuka data kelas pada gambar 6 .

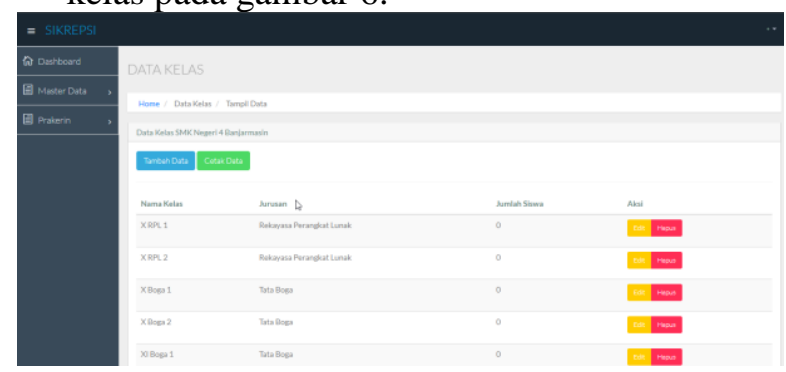

Gambar 4. Antarmuka Data Kelas

c) Antarmuka Data Jurusan

Halaman data jurusan menampilkan data jurusan yang ada di SMK Negeri 4 Banjarmasin. Data yang ditampilkan yaitu: nama jurusan, jumlah kelas, dan jumlah siswa dalam setiap jurusan. Berikut tampilan antarmuka data jurusan pada gambar 5.

Jurnal Ilmiah "Technologia"

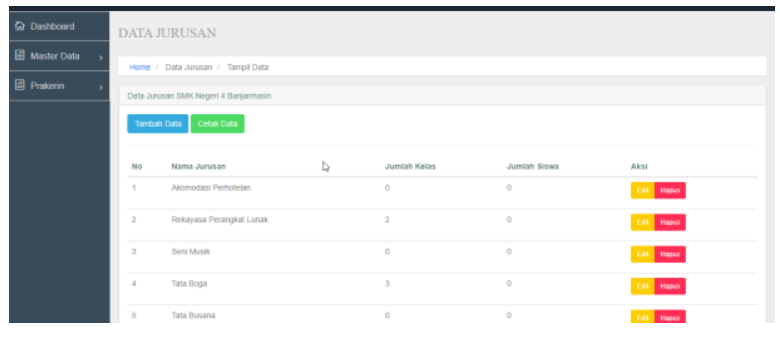

Gambar 5. Antarmuka Data Jurusan

d) Antarmuka Data Tahun Ajaran

Halaman data tahun ajaran menampilkan data tahun ajaran di SMK Negeri 4 Banjarmasin. Berikut tampilan antarmuka data tahun ajaran pada gambar 6 .

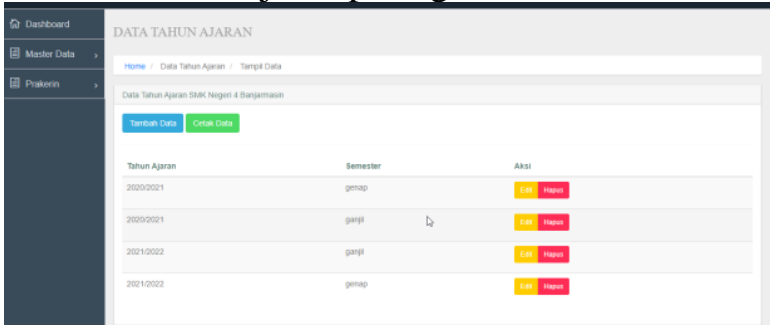

Gambar 6. Antarmuka Data Tahun Ajaran

e) Antarmuka Data Siswa

Halaman data siswa ini digunakan untuk menampilkan data siswa SMK Negeri 4 Banjarmasin. Pada halaman ini menampilkan informasi siswa seperti NIS, nama lengkap, tempat tanggal lahir, kelas dan nomor telepon siswa. Halaman data siswa ini hanya bisa diakses bagi pengguna guru, admin. Sedangkan untuk pengguna siswa tidak ditampilkan. Berikut tampilan halaman siswa pada gambar 7

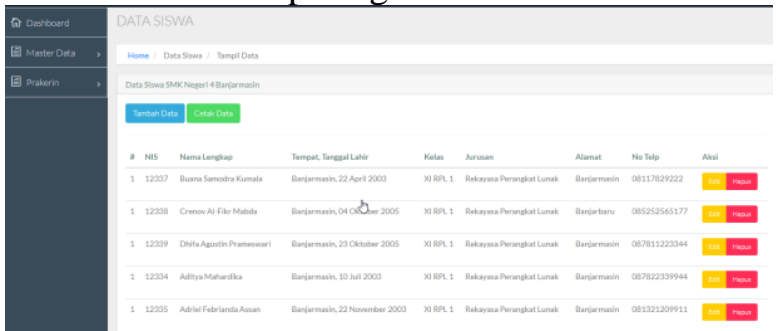

Gambar 7. Antarmuka Data Siswa

f) Antarmuka Data Tempat Prakerin Halaman ini bertujuan untuk menampilkan informasi data tempat prakerin yang bekerja sama dengan sekolah SMK Negeri 4 Banjarmasin. Halaman ini menampilkan 
nama tempat prakerin, alamat tempat prakerin, no telepon. Berikut tampilan antarmuka data tempat prakerin pada gambar 8 .

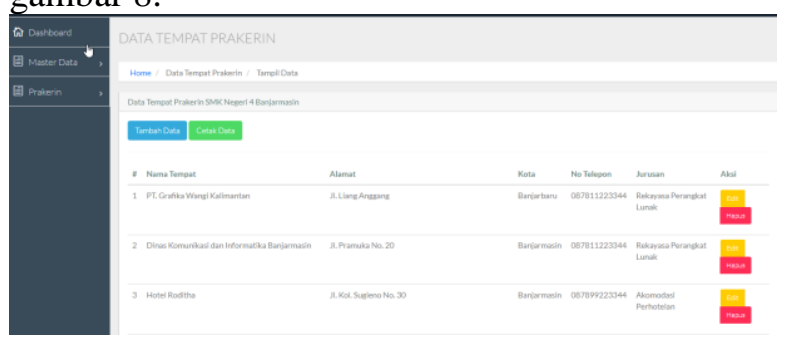

Gambar 8. Antarmuka Data Tempat Prakerin

g) Antamuka Data Guru

Halaman ini menampilkan informasi datadata guru SMK Negeri 4 Banjarmasin. Informasi yang ditampilkan yaitu nip, nama lengkap, alamat, no telepon. Berikut tampilan halaman guru pada gambar 9 .

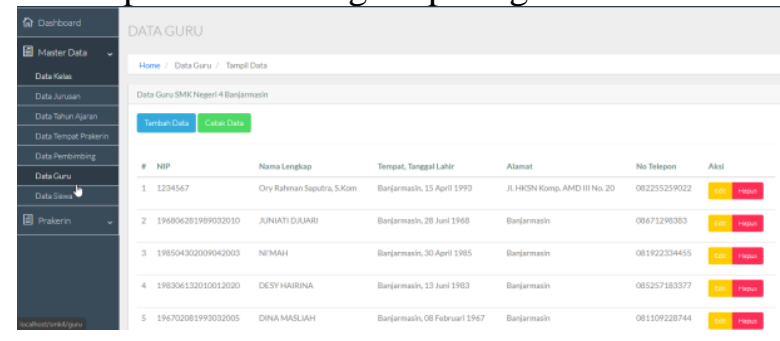

Gambar 9. Antarmuka Data Guru

h) Antarmuka Pemilihan Tempat Prakerin Halaman antarmuka data pemilihan tempat prakerin ini adalah halaman yang digunakan untuk menampilkan data tempat pelaksanaan prakerin bagi siswa. Pada halaman ini menampilkan nama tempat prakerin, tanggal mulai, tanggal selesai pelaksanaan prakerin, nama guru pembimbing dan jumlah siswa yang melaksanakan prakerin di tempat tersebut. Berikut halaman antarmuka data pemilihan tempat prakerin pada gambar 10 .

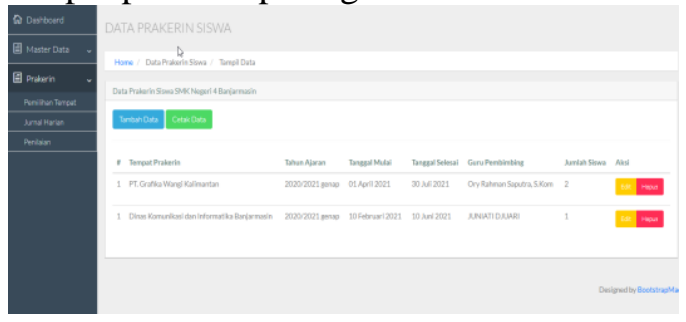

Gambar 10. Antarmuka Data Pemilihan Tempat

Jurnal Ilmiah "Technologia" i) Antarmuka Tambah Pemilihan Tempat Halaman tambah pemilihan tempat prakerin ini digunakan untuk proses pemilihan tempat prakerin siswa. Untuk memilihkan tempat prakerin, data yang diinput yaitu nama tempat prakerin, tanggal mulai dan tanggal selesai, nama guru pembimbing, dan nama-nama siswa yang melaksanakan prakerin di tempat tersebut. Pemilihan tempat prakerin ini bisa memilih beberapa siswa sekaligus dalam 1 tempat prakerin. Halaman tambah pemilihan tempat prakerin ini hanya bisa diakses oleh pengguna dengan status Admin. Berikut tampilan antarmuka tambah pemilihan tempat pada gambar 11.

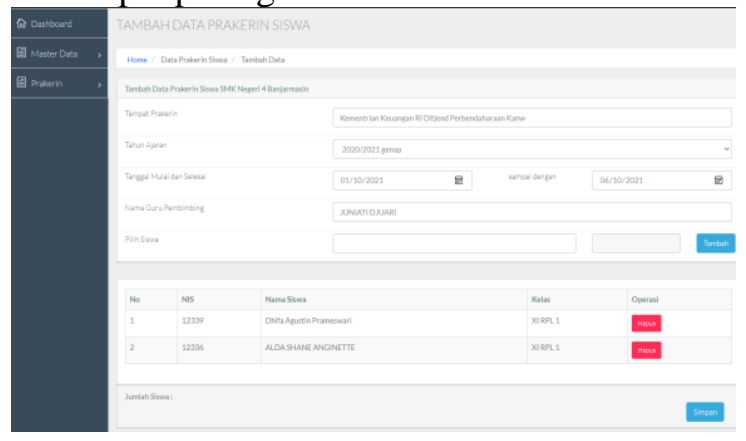

Gambar 11. Antarmuka Pemilihan Tempat Prakerin

j) Antarmuka Jurnal Kegiatan Prakerin Halaman ini digunakan untuk menampilkan data jurnal atau agenda kegiatan yang sudah diinputkan oleh siswa. Pada halaman ini menampilkan informasi seperti nama siswa, tempat prakerin, tanggal kegiatan, isi kegiatan dan status. Data agenda yang dimasukan oleh siswa awalnya statusnya adalah pending. Kemudian dari akun pembimbing prakerin di lapangan dapat memverifikasi agenda tersebut apakah sesuai yang dikerjakan oleh siswa. Apabila status jurnal atau agenda kegiatan sudah diverifikasi semua, maka agenda tersebut bisa dicetak oleh siswa. Berikut tampilan antarmuka data agenda atau jurnal kegiatan siswa prakerin pada gambar 12 . 


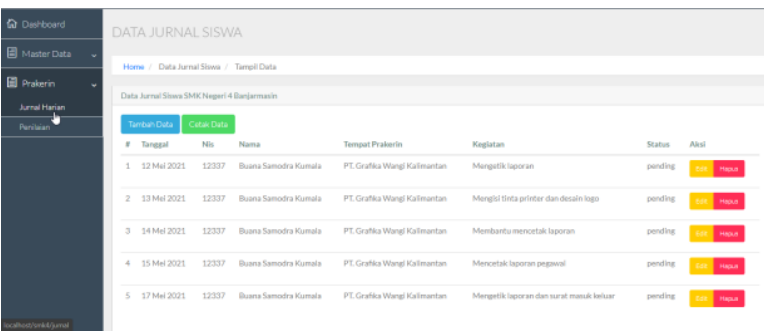

Gambar 12. Antarmuka Data Jurnal Siswa

\section{KESIMPULAN}

Dari penelitian ini, dengan adanya aplikasi monitoring kegiatan praktek kerja industri siswa SMK ini dapat ditarik kesimpulan yaitu:

1. Membantu pihak sekolah dalam mengelola data PRAKERIN siswa.

2. Mempercepat informasi jurnal atau kegiatan siswa dalam melaksanakan PRAKERIN

3. Memudahkan pihak sekolah dalam memberikan atau menyajikan laporanlaporan yang berkaitan dengan data PRAKERIN siswa.

\section{REFERENSI}

[1] Baiduri, Mochamad dan Susilawati, Erna. "Perancangan Sistem Informasi Praktek Kerja Industri di SMK Bakti Nusantara $\backslash 666$ Cileunyi”. Jurnal JAMIKA Manajemen Informatika. Vol 9 No 2. 2019

[2] Ayu, Fitri dan Permatasari, Nia. "Perancangan Sistem Informasi Pengelolaan Data Praktek Kerja Lapangan (PKL) Pada Devisi Humas PT. Pegadaian”. Jurnal IntraTech. Vol 2 No 2. 2018

[3] Maharani, Septya, Widagdo, Putut Pamilih dan Hatta, Heliza Rahmania. "Rancang Bangun Sistem Informasi Praktek Kerja Lapangan (PKL) di Fakultas Ilmu Komputer dan Teknologi Informasi Universitas Mulawarman". Informatika Mulawarman: Jurnal Ilmiah Ilmu Komputer. Vol 13 No 2. 2018

[4] Anhar. (2010). PHP dan MySQL Secara Otodidak. Jakarta: Agromedia Pustaka. Jurnal Ilmiah "Technologia"
[5] Jogiyanto, \& Hartono. (2009). Analisis \& Desain Sistem Informasi. Yogyakarta: Andi Ofset.

[6] Prayitno. (2003). Wawasan dan Landasan Bimbingan Konseling. Jakarta: Depdiknas.

[7] Wahyudi, B. (2010). Perancangan Sistem. Bandung: Informatika.

[8] Safaat, Nazaruddin H, 2014, Pemrograman Aplikasi Mobile Smartphone dan Tablet PC Berbasis Android, Bandung, Informatika. 